\title{
Obstáculos à burocratização de uma vila no sertão paulista, século XIX
}

\section{Obstacles to bureaucratization in a small paulista country town in the 19th Century}

\author{
Edson Fernandes*
}

\begin{abstract}
Resumo
Este trabalho trata dos obstáculos à burocratização e à institucionalização da ordem político-eleitoral, religiosa, administrativa e judiciária numa vila do interior paulista na segunda metade do século XIX. A região, compreendida pelos rios Tietê e Paranapanema, caracterizou-se por ser durante algumas décadas daquele século a fronteira do povoamento. Daquele sertão, pouco se sabia além dos relatos esporádicos dando conta da presença de indígenas, alvo dos constantes apelos das autoridades locais ao governo provincial. Os obstáculos à burocratização das instituições ultrapassavam os limites da elite detentora do poder e, por contágio ou apadrinhamento, atingiam as camadas populares que, desta forma, resistiam a adotar as medidas normatizadoras das autoridades locais.
\end{abstract}

Palavras-chave: Fronteira; interior paulista; burocratização.

\begin{abstract}
This workaddresses theobstaclestobureaucratization and institutionalization of the judicial, administrative, religious and political-electoral order in a small country town in the second half of the $19^{\text {th }}$ century in the Brazilian state of São Paulo. The area, located between the Tietê and Paranapanema rivers, had been considered for decades the frontier of the settlements. Very little was known about those "sertões" (the hinterland) except for some descriptive literature that indicated the presence of indigenous people and the constant appeals from local authorities to the provincial government. The obstacles to bureaucratization of institutions did not come from the elites exclusively and, by way of contamination or patronage, reached the lower social classes unwilling to adopt regulating measures issued by local authorities.
\end{abstract}

Key words: Frontier; hinterland; bureaucratization

"Doutor em História Social (Unesp/Franca).E-mail: edsonfernandes62@outlook.com 
Por algumas décadas do século XIX, a freguesia/vila de Lençóes foi uma boca do sertão paulista - ponto de apoio de expedições que demandavam o grande sertão em que se caracterizava a porção ocidental da província de São Paulo, vasto território delimitado pelos rios Tietê e Paranapanema.

A princípio, um diminuto núcleo urbano em torno do qual gravitavam inúmeros bairros rurais, o povoado foi por décadas a fronteira do povoamento do território paulista, além do qual havia uma imensa área cujo conhecimento se baseava em relatos esporádicos de exploradores, padres e aventureiros de toda espécie. Nestes relatos, a existência de grupos indígenas, entre os quais os Kaingang, eram uma constante.

Esta área foi assim descrita pelo juiz municipal Joaquim Antonio do Amaral Gurgel, em correspondência às autoridades provinciais no ano de 1876:

É bastante attender que este termo é vastissimo em territorio, é o $1^{\circ}$ da Provincia; da sede do termo aos campos novos de José Theodoro, que são os ultimos moradores, tem uma extensão de cincoenta leguas mais ou menos, a fóra os terrenos desconhecidos que estendem pelas margens do rio Paranapanema até a sua foz no rio Paraná, e deste rio subindo acima até a embocadura no rio Tiete, e deste subindo até pouco acima do lugar denominado porto embocadura de Lençóes; occupando uma área de muitissimas leguas. A população não tem menos de vinte e tantas mil almas, cresce quase que diariamente com a emigração mineira para o lado do sertão. ${ }^{1}$

A presença dos índios e sua ameaça à ocupação da terra pelos brancos se prolongou por quase todo o século XIX. Eram constantes os apelos às autoridades provinciais no sentido de fornecer reforço policial que fizesse frente aos ataques indígenas ou para a instalação de aldeamentos onde pudessem ser catequizados. Relatórios oficiais insistiam na conveniência de serem fundados aldeamentos "em Lençóis, Botucatu e Campos Novos, onde há excelentes terras de cultura e, onde, errantes, vagam para cima de 1.000 índios Xavantes e Coroados"2.

Ainda no final do século, quando a fronteira do povoamento já se deslocava léguas a oeste, criando novos núcleos urbanos como Agudos e Bauru, a presença do perigo não passou despercebida aos olhos de ao menos uma moradora que havia se mudado para a região com a família para abrir uma

\footnotetext{
${ }^{1}$ Quando não houver indicação em contrário, as citações de juízes e promotores são retiradas de: Caixa 296, Ordem 1091, Ofícios diversos 1849-1891, Pasta 2, AESP; Caixa 44, Ordem 4789 Anos 1872-1891, AESP. ${ }^{2}$ Relatório do Presidente da Província de São Paulo, 1870. São Paulo, 1870, p. 28 apud LIMA, J.F.T., 1978. p. 133.
} 
fazenda de café (Fazenda do Engenho), em 1896, quando tinha 21 anos. Floriza Ferraz da Silveira Corrêa escreveu suas memórias em 1947. Sobre a época de sua chegada à região, diz que morava em uma casa:

[...] colocada na beira de uma estrada aberta e franca por onde transitavam n'aquella épocha, em demanda de outros sertões mais longincuos como o Salto Grande do Avanhandava, Espírito Santo do Turvo, Rio do Peixe, tranzitavam por ali rente de nossa casa, os célebres e temíveis fascinoras João Modesto e Dioguinho, que eram o terror de nossa zona. Elles faziam suas aparições de supreza, e geralmente nas vendas ao lado das estradas, onde provocavam conflitos e mortes, obrigando a todo o mundo a andar armado de garrucha e de revolveres [...]. Viviam escondidos nas zonas entre Jahú, Campos Salles, Banharão, Barra Bonita e Pederneiras. Conheciam todas as estradas e desvios, andavam até por dentro das matas para não serem encontrados. Muitas vezes abuzavam porque n'aquelle tempo não havia policiamento. ${ }^{3}$

Após relatar um problema com os colonos, Floriza compreende "os perigos que nos cercavam n'aquelle lugar isolado" receando "malfeitores e valentões que atravessavam pelo nosso terreiro e caminhos".

Este povoamento ralo e disseminado marcou por algumas décadas a fronteira oeste. Martins caracteriza a fronteira como o lugar da alteridade, a um só tempo lugar de descoberta do outro e de desencontro:

[...] não só o desencontro e o conflito decorrentes das diferentes concepções de vida e visões de mundo de cada um desses grupos humanos. 0 desencontro na fronteira é o desencontro de temporalidades históricas, pois cada um desses grupos está situado diversamente no tempo da História. [...] A fronteira só deixa de existir quando o conflito desaparece, quando os tempos se fundem, quanto a alteridade original e mortal dá lugar à alteridade política, quando o outro se torna a parte antagônica do nós. ${ }^{4}$

Encontro dos que são diferentes entre si, cada um situado num tempo da História: índios e civilizados; grandes proprietários de terra e camponeses pobres. Assim foi o entorno do povoado de Lençóes praticamente até poucos momentos antes do fim da ordem monárquica, embora fosse, aos poucos, sendo construída a ordem institucional.

\section{A administração dos problemas}

Algumas décadas separam o pequeno núcleo de povoamento de meados do século XIX daquele outro já minimamente consolidado e que já havia

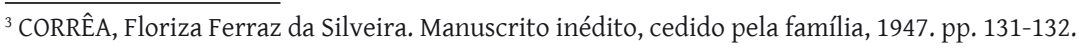

${ }^{4}$ MARTINS, José de Souza. Fronteira: a degradação do outro nos confins do humano. São Paulo: Hucitec, 1997. pp. 150-151.
} 
passado a condição de boca do sertão para outros povoados, no final do século. A situação de fronteira foi, aos poucos, deixando de ser uma característica daquele território, paralelamente à construção de toda uma estrutura administrativa, político-eleitoral, judiciária e educacional, ou seja, à construção de uma estrutura institucional.

Esta ordem, é importante salientar, continuou sendo construída muito tempo após o fim da monarquia. Até porque a proclamação da república levou à necessidade da criação e/ou adequação dos órgãos administrativos à nova ordem que então se estabelecia no país. As relações com a igreja alteraram-se, visto todo o processo de laicização do estado, assim como uma nova postura no que se refere aos assuntos educacionais ganhou corpo.

Os obstáculos à burocratização das administrações locais foram levantados por Maria Sylvia de Carvalho Franco ao analisar o caso de Guaratinguetá. As dificuldades apontadas pela autora também estão presentes na vila de Lençóes, a saber:

De uma parte, um servidor público cujos vínculos com o ambiente em
que vivia não eram compensados por uma atitude profissional capaz de
garantir um certo rigor no desempenho de suas atribuições funcionais;
de outro lado, o descuido em formalizar as práticas administrativas, o que
seguramente advinha da falta de importância mesma dessas providências,
visto como referidas práticas se alicerçavam, na realidade, sobre uma ordem
consuetudinária. ${ }^{5}$

Some-se a isto a "a própria situação crônica de penúria, em que se encontravam todos os níveis da Administração", além da "carência de prédios e instalações para o funcionamento de seus serviços", e estará traçado o panorama administrativo de Lençóes.

Em meados do século XIX, este bairro era formado por "cincoenta a sessenta fogões", alguns deles resultados de posse que remontavam a "vinte tantos annos". Os primeiros pedidos de criação de uma freguesia no "campo dos Lençóes" foram respondidos negativamente pelas autoridades, visto que "ainda não ha povoação nem capela propriamente ditas conforme se collige do officio do Subdelegado de Botucatú, o numero de seus habitantes é limitadissimo, sendo alem disso muito pobres e vivendo disseminados". A dificuldade de encontrar "homens capazes de exercer empregos" será uma constante nas primeiras décadas de existência de Lençóes. Em parte, isto se devia ao incipiente povoamento da região, mas quando esta situação foi su-

${ }^{5}$ FRANCO. Maria Sylvia de Carvalho. Homens livres na ordem escravocrata. 4. ed. São Paulo: Ed. UNESP, 1997. p. 125. 
perada, continuou prevalecendo aquilo que Sérgio Buarque de Holanda qualificou de "mentalidade de casa-grande", criando embaraços insuperáveis à burocratização do serviço público:

\begin{abstract}
Num país que, durante a maior parte de sua existência, foi terra de senhores e escravos, sem comércio que não andasse em mãos de adventícios ambiciosos de riquezas e de enobrecimento, seria impossível encontrar uma classe média numerosa e apta a semelhantes serviços. ${ }^{6}$
\end{abstract}

$\mathrm{Na}$ ausência de "homens capazes de exercer empregos", a estrutura político-institucional foi seqüestrada por uma elite de potentados ligados por laços de parentesco. No entanto, este controle não se deu sem discórdias entre facções desta elite.

Criada uma freguesia no incipiente povoado, em abril de 1858, constituiu-se o patrimônio de Nossa Senhora da Piedade dos Lençóes a partir da doação de uma área de campos e matos, feita por alguns fazendeiros, em julho daquele mesmo ano. A área formava um rudimentar quadrado de quinhentas braças de lado, sendo que dois lados adjacentes correspondiam aos rios Lençóes e da Prata. O núcleo urbano começava a se constituir.

A preocupação da igreja com as obrigações religiosas daqueles que vivam no sertão não correspondia à existência de vigários para tal fim. Em Lençóes, até a chegada do primeiro padre, em fevereiro de 1862, o serviço religioso era bastante precário.

Entre os dias 20 e 23 de novembro de 1857, o padre Salvador Ribeiro dos Santos Mello fez vários batizados na "capellinha dos Lençóes": 33 crianças, sendo 16 meninas e 17 meninos, inclusive alguns filhos de escravos. Como não havia uma presença constante de padre na freguesia e o deslocamento até a vila de Botucatu era uma aventura para muitos dos moradores do sertão, muitos pais esperavam a vinda do padre para batizar os filhos, do que resulta que muitos deles já estavam em idade avançada de vários meses ou até anos.

Meses depois, o mesmo padre voltou, passou mais alguns dias por Lençóes, entre 22 e 23 de março de 1858 , e batizou mais 11 crianças. No dia 15 de outubro de 1858, o padre Salvador saiu de Fortaleza (distrito que daria origem à futura Bauru), onde havia batizado algumas crianças e, passando por Lençóes, batizou mais 19 crianças, entre os dias 15 e 16. Assim fazia o padre enquanto o povoado não dispunha de um, saia de Botucatu e realizava uma peregrinação pelas capelas da região, ministrando os sacramentos para aquela gente perdida no sertão.

${ }^{6}$ HOLANDA, Sérgio Buarque de. Raízes do Brasil. 26. ed. São Paulo: Companhia das Letras, 1995. pp. 87-88. 
Estabelecido o primeiro padre da freguesia, Antonio de Sant'anna Ribas Sandim, a construção de uma igreja digna deste nome levaria muitos anos a se concretizar. Ainda em 1870, um ofício da câmara da vila às autoridades provinciais dava conta da precária situação da igreja e pedia à "Assembléia Provincial uma quota de dez contos de reis para a construcção da nova matriz nesta villa, com o que fará V. Excia um dos mais almejados benefícios deste lugar."’

A elevação à vila, em abril de 1865, possibilitou a instalação de uma câmara municipal. Nas primeiras sessões, já ficaram evidentes a precariedade das instalações e as dificuldades financeiras que a nova vila teria pela frente. Em ofício enviado ao governo provincial no primeiro dia de funcionamento da câmara, os vereadores pedem

[...] a quantia de trezentos mil reis, valor em que foi orçado para a compra dos Livros precizos moveis e para as mais despezas eventuaes, sem o que, se acha inabilitada a cumprir seus deveres, visto a dacta em que começam os seus trabalhos. ${ }^{8}$

No entanto, a resposta não foi das mais animadoras por parte do tesouro provincial: se não há recursos na Câmara, "deve esperar até que os tenha, se de outro meio não poderem lançar mãos os vereadores, que entre si poderão resolver convenientemente esses embaraços". ${ }^{9}$

Aos olhos das autoridades locais, o progresso da vila estava ligado à necessidade de sair do isolamento, por isso era constante o pedido para abertura de estradas e construção de pontes para todos os lados em que houvesse uma povoação: para São Domingos, "atalhando algumas voltas que existem", para Piracicaba, "passando pela freguesia dos Remédios", para o porto do Tietê, para Botucatu, "visto que a existente é cheia de voltas e arruinada". Uma estrada para Avanhandava era um sonho recorrente, conforme os vereadores na sessão de 12 de julho de 1866:

[...] visto ser aquelle lugar ainda muito além pertencente a este districto onde contem grande numero de moradores que se achão preteridos de communicarem a esta povoação por estarem cercados por um espaço de mattas incultas que separa estes dois lugares[...].

\footnotetext{
${ }^{7}$ Caixa 296, Ordem 1091, Ofícios diversos 1849-1891, AESP.

${ }^{8}$ Quando não houver indicação em contrário, as citações que envolvem a Câmara Municipal são retiradas do Livro de Atas 1866-1886, ACMLP.
}

${ }^{9}$ Caixa 296, Ordem 1091, Ofícios diversos 1849-1891, Pasta 1, AESP. 
A penúria financeira da incipiente vila ("o município pouco rende e não da para remediar as necessidades”) era um impeditivo à construção da ordem administrativa. Quando o porteiro da câmara solicitou o pagamento de seus ordenados, ouviu como respostas que seria paga apenas a metade de seus vencimentos, "devido a escassez de reditos". Obras deixavam de ser construídas, como o matadouro, rejeitado pela insuficiência de recursos. A escassez de meios financeiros, como notou Franco, "constituiu o entrave fundamental ao desígnio de burocratizar a administração".

Em parte, a penúria era devido à incúria na cobrança dos impostos municipais, "pela falta de energia de quem os arrecada". Talvez se possa dizer, como faz Franco em seu já citado estudo, que a conduta do servidor público:

Orientada mais pelos vínculos que o prendiam aos interesses de seu meio social, que pela lealdade para com seu empregador distante e desmaterializado, começa a tornar-se inteligível quando se evidencia como era de fato ainda rudimentar o próprio conjunto de fórmulas que disciplinava a realização dos objetivos do Estado. ${ }^{10}$

A citada "situação crônica de penúria" levava a outro fenômeno identificado por Franco em Guaratinguetá, a aplicação de recursos privados em serviços públicos. O presidente da câmara de Lençóes, Generoso Antonio de Oliveira, declara que "a Câmara até hoje não tem auxílio do governo. Como presidente, tem feito às suas custas o serviço e pode continuar assim enquanto for presidente". Diz, no entanto, ser necessário alugar uma casa para as sessões.

Em 26 de março de 1870, o presidente indicou que a câmara alugasse uma sala para as sessões e "que tenha os mais cômodos que são necessários". Vereadores foram nomeados para "fazerem o contrato de uma sala com duas alcovas que sejam próprias para as sessões desta câmara e sessões do júri". No final daquele ano, tendo a casa passada às mãos de outro dono e este querendo duzentos mil-réis por ano, novamente fez-se necessário a procura de outra, de preço mais barato.

A utilização de recursos privados em obras públicas, assim como de propriedades particulares, levava à:

[...] extensão do controle pessoal a todo o patrimônio do Estado. A passagem é rápida: o homem que sustenta com recursos particulares as realizações próprias do governo está subjetivamente pronto para considerar como seu o conjunto de bens públicos confiados à sua guarda. ${ }^{11}$

\footnotetext{
${ }^{10}$ FRANCO, op. cit., p. 42. (destaques da autora).

${ }^{11}$ Ibidem p. 131.
} 
A confusão entre a coisa pública e a esfera privada fica nítida quando uma nova legislatura teve início e a câmara oficiou ao ex-presidente exigindo os livros e papéis pertencentes ao arquivo. Apenas em março do ano seguinte compareceu o ex-presidente e apresentou o livro que servia de receita e despesa, tão mal detalhado que pouco serviu para os vereadores. 0 descuido era total: pelo exame do livro verificaram haver "um saldo a favor desta Câmara vindo da passada administração da quantia de $328 \$ 020$, sem que se saiba em poder de quem existe essa quantia".

A apropriação de um bem público pela entidade privada não se fazia apenas por aqueles encarregados da administração. Por várias vezes, cidadãos foram multados por interromperem caminhos.

A sessão de 16 de fevereiro de 1872 deliberou enviar o fiscal, auxiliado pela polícia, para intimar e multar o cidadão Salvador Vieira de Andrade por ter impedido a passagem numa "estrada publica e caminhos de sacramento de varios habitantes e isto com um portão, e chave impedindo assim o transito publico desde o dia quinze das quatro horas da tarde mais ou menos em diante". A negação da abertura da estrada e do pagamento da multa acarretaria ao cidadão oito dias de prisão.

A falta de pessoal habilitado para a função pública, mesmo para tarefas que exigiam pouco preparo intelectual, era outro fator que debilitava a administração. O pedido de demissão do fiscal suplente Alexandrino José de Almeida não foi aceito "porque não havia n'esta Villa pessoa idônea que quisesse acceitar o mencionado cargo".

A saúde pública também era alvo das atenções das autoridades, mas também aí as dificuldades e a recusa dos moradores de se "enquadrar" na ordem em construção tornavam a tarefa vã. Em abril de 1867, um vereador discorreu sobre a necessidade de abertura de "um exgoto no fundo do quintal de José Rodrigues da Silva para dessecar uma lagoa alli existente que se torna pestifera, e que a bem da salubridade publica julgada mister esse serviço". No ano seguinte, a câmara deliberou exigir providências do fiscal a respeito da existência no quintal de um morador de um lago profundo que "conserva água estagnada d'onde se desenvolve miasma que traz a epidemia d'intermittentes e outras febres, e que como se acha este lago nas margens do rio Lençóes, por isso indica a precisão de ser esgotado".

Até o sepultamento era objeto das atenções. Algumas "pessoas do sitio que trazem cadáveres para sepultar no cemitério publico d'esta Villa, costumão a fazerem sepulturas rasas do que resultava a exhalação pútrida d'aquelles cadáveres", daí a necessidade de solicitar providências ao pároco. 
À resistência da população podia corresponder uma maior repressão das autoridades. Quando José Pereira de Lima foi multado duas vezes pelo fiscal devido ao bloqueio de um caminho, foi determinado pela câmara que o mesmo fosse "notificado novamente para fazer o dito caminho porque tornou-se rebelde deveria ser multado no duplo".

Desde o início da formação de Lençóes já havia uma grande preocupação das autoridades com o crescimento desordenado que poderia comprometer a aparência do povoado. São várias indicações dos vereadores no sentido de manter o "formoseamento" das ruas e praças, além da necessidade de manutenção de pontes e a eliminação de animais ferozes que perambulavam pela vila, pois ainda havia costume das pessoas de amansarem "animais bravos no perigo de offender as pessoas e crianças pelas ruas devido a falta das respectivas multas".

A preocupação com a aparência fica patente numa indicação do presidente da Câmara, em janeiro de 1867, em que solicita ao fiscal:

[...] para que não conceda datas de terrenos devolutos no patrimonio desta Villa para construção de prédios em lugares desmembrados dos que se achão occupados afim de que fique assim encorporada a povoação e formoseada [...].

Em abril do mesmo ano, as autoridades ordenam a limpeza das testadas das casas e quintais existentes na vila, "para formoseamento da mesma e para facilitar o transito do povo". Ainda no mesmo abril, a câmara atesta a necessidade "que há de serem rebocadas e caiadas todas as casas desta Villa para formoseamento da mesma".

São várias as determinações para que os proprietários providenciassem a limpeza das testadas das casas e quintais, mas a negligência deles era uma reclamação constante do fiscal encarregado de verificar a situação da limpeza e ordem públicas. Não é à toa que estes pedidos eram recorrentes na câmara. Em pelo menos um momento, em janeiro de 1869, a câmara deliberou oficiar ao subdelegado de polícia auxiliar o fiscal nesta tarefa.

A função normatizadora da câmara encontrava barreiras no mundo real, palco de desavenças, discórdias, disputas pelo controle efetivo das instâncias de poder e do acesso aos meios de sobrevivência, principalmente a terra, mas também os espaços públicos.

A preocupação em preservar certas áreas do patrimônio para finalidades específicas emerge da documentação. Em abril de 1867, um vereador indica encaminhar ofício ao fiscal "para que não concedesse datas de terreno no largo que se acha em frente da casa de Antonio Marques Ribeiro, para 
ficar destinado para parada das boiadas que paçassem n'esta Villa, e que ficasse denominado largo do Riachuelo".

Em agosto de 1869, o "formoseamento" da vila volta a ser assunto. 0 presidente da câmara afirmou que alguns trechos de ruas estavam cobertos de capim e mato pela negligência de proprietários que não tinham o devido cuidado e que esta situação "não só concorre para o desformoseamento da povoação como também para conservação das cobras que há com abundancia".

Embora houvesse esta preocupação por parte das autoridades, nem sempre o "formoseamento" foi prioridade para aquela gente que vivia tempos difíceis. Casas surgiam aqui e acolá, nem sempre dentro dos padrões que as autoridades ditavam. A necessidade foi, em muitos casos, a única arquiteta disponível.

A elaboração do código de posturas para a vila foi um capítulo à parte na construção da ordem administrativa. Inicialmente, foram adotadas as posturas de Botucatu, conforme sessão de 21 de julho de 1867:

[...] visto que esta Câmara ainda não pôde formatar o seo código de posturas em consequiência de ser o município composto somente do districto desta Villa, e estar na esperança de conseguir d'Assembleia Provincial a passagem do districto de São Domingos para este município para depois organizar suas posturas.

O pedido de autorização para continuar utilizando as posturas daquela vila repetiu-se em 1868 e 1869.

A falta de preparo para o exercício de atividades não era "privilégio" das autoridades encarregadas da administração pública. Lauro Maria Barreiros, agente do correio, foi acusado de negligência e má-fé. Segundo o juiz de Lençóes, em ofício reservado de dezembro de 1882, o referido agente teria se ausentado para Botucatu "por mais de uma vês", deixando em seu lugar alguém que colocava em risco a inviolabilidade das correspondências:

Para provar a V. Sa. que elle não está nas condições de ser Agente do Correio pela falta de bom siso ou má fé refiro um facto que se deu o Presidente da Provincia enviou uns autos a este Juiso, elle abriu os papeis pensando que era mala do correio, mas verificando que não era, mandou levar ao Dํㅏ Juis Municipal, este depois que viu devolveu ao Agente, disendo que não era para elle, nesses papeis vinha uma denuncia contra o mesmo Juis Municipal, que tornou-se publico immediatamente.

As alegações do agente para suas faltas procuram sensibilizar as autoridades. Neste caso, confundem-se questões privadas com a impessoalidade 
do serviço público. Afirmou ele que "gemia n leito da dôr minha velha Mãi, esse ente aquem no mundo mais presava". A dúvida o atormentava e ele "vagou de conjectura em conjectura, de um lado o dever do cargo e de outro a Mãi moribunda que chamava o filho na derradeira hora!!!"12.

Ora é o agente do correio acusado de faltar ao serviço e de violar a correspondência, ora é o cidadão que se faz passar pelo que não é, como um que se diz farmacêutico formado e licenciado sem o ser, levando as autoridades a pedir o fechamento de sua farmácia. Ou então, segundo denúncia de um morador, a venda de drogas deterioradas em vasilhames e com rótulos novos na única farmácia da vila.

A falta de recursos médicos colocados à disposição da população levava à elevação do tom dramático nos apelos ao governo provincial. O "flagelo das bexigas" era uma constante visita à vila. Assim foi em 1870, o que fez com que a câmara solicitasse ao governo provincial o envio de vacinas, remédios e alimentos para os pobres. A população "orrorizada fogem $\mathrm{p}^{\mathrm{a}}$. longe, so fica na Villa os pobres que não podem sair”, é o clamor das autoridades locais ${ }^{13}$.

No ano seguinte, a câmara deliberou levar, "pela segunda vez", ao presidente da província, “a necessidade de pus vacínico”. Em 1872, a bexiga ainda é um problema e o delegado de polícia faz o que pode, "contractando infermeiro, hospital botica e curandeiros por falta de medicos habilitados, podendo V. Ex $x^{\mathrm{a}}$. nos fornecer com um que tenha habilitaçõens, por cuja falta de socorro já foi sepultado um escravo" 14 .

A incúria atingia também o serviço religioso. Ao assumir a paróquia da vila de Lençóes, o padre José Magnani encontrou os livros de registro paroquiais em estado bastante precário, "rasgadas diversas folhas e jogados estes destroços no fundo de uma gaveta na sacristia, em aberto, a mercê de todo". Magnani fez a encadernação, a capa e todos os consertos, deixando-os outra vez em boas condições, mas pergunta-se se os livros sofrerão "outra vez a mesma sorte que por duas vezes lhe tocou? Continuará sempre o ódio de sacerdotes ao meu nome e ao meu serviço?" ${ }^{15}$. Ao desleixo, somam-se as rixas pessoais e o ódio de uns contra outros, precarizando ainda mais a administração do serviço público.

Se a escassez de recursos era uma reclamação recorrente das autoridades, aos moradores não passavam despercebidas as precárias condições

\footnotetext{
${ }^{12}$ Caixa 296, Ordem 1091, Ofícios diversos 1849-1891, AESP

${ }^{13}$ Ibidem.

${ }^{14}$ Caixa 296, Ordem 1091, Ofícios Diversos 1849-1891, Pasta 1, AESP

${ }^{15}$ Observações no final do Livro 12, ACB.
} 
da vila no que concerne aos meios de subsistência. Quando o fazendeiro Joaquim Martins de Siqueira recorreu à Assembléia Provincial solicitando que sua propriedade - dividida em duas partes devido à uma divisão territorial estabelecida pelo governo em 1882, entre Lençóes e Botucatu - ficasse toda ela no termo desta última povoação, argumentou que a divisão o prejudicou porque:

[...] todos os seos negocios e relações commerciaes são para Botucatú, que vai sempre em progresso, pessoal muito melhor, quando Lençóes não tem os mesmos recursos e nem meios de transações e é por isso q. o supp.e vem requerer a esta respeitavel Assemblea a passagem do sitio de sua propriedade para o termo de Botucatú afim de não continuar a soffrêr em seus interesses. ${ }^{16}$

\section{A arbitragem dos conflitos}

Retomando Martins, para quem "a fronteira só deixa de existir quando o conflito desaparece" ${ }^{17}$, a vila de Lençóes não perdeu de todo sua condição de fronteira no limiar da nova ordem republicana. Mesmo surgindo mais a oeste outros núcleos de povoamento, as características da fronteira ainda se faziam presentes.

O pedido de criação de subdelegacia, feito em 1851 e só atendido seis anos mais tarde, deixa entrever o potencial de conflitos que os "campos dos Lençóes" apresentavam. A falta de pessoal qualificado para o exercício dos serviços públicos - tantas vezes lembrada pelas autoridades - jogava nas mãos de uma elite letrada e aparentada entre si os principais cargos da vila. E freqüentemente os usava em benefício próprio ou dos seus, para manter sob controle os camponeses pobres ou como arma de vingança contra os inimigos políticos.

A imunidade da esfera doméstica aos efeitos da modernização vem de longa data, como já demonstrou Holanda:

\footnotetext{
"Sempre imerso em si mesmo, não tolerando nenhuma pressão de fora, o grupo familiar mantém-se imune de qualquer restrição ou abalo. Em seu recatado isolamento pode desprezar qualquer princípio superior que procure perturbá-lo ou oprimi-lo."18
}

\footnotetext{
${ }^{16}$ Documento EE. 83. 4.1, ALESP-DAH.

${ }^{17}$ MARTINS, op. cit., p. 151.

${ }^{18}$ HOLANDA, op. cit, pp. 81-82.
} 
O coronel Joaquim de Oliveira Lima tomou posse como subdelegado de polícia em junho de 1859. Anos depois, em 1863, era apontado por José Baptista do Nascimento como um dos dois potentados que "praticão as maiores injustiças, violão todos os direitos e tudo usurpão" ${ }^{19}$. O outro potentado era seu concunhado, José Inocência da Rocha.

Anos depois, em 1882, o mesmo coronel Oliveira Lima envolvia-se numa questão de terras contra a "família Gouveia", tendo o apoio do juiz Amaral Gurgel e de outros depoentes, gente que se reunia na casa do juiz para jogar, amigos que disso tiram "aquilo que podem gastar com serveja ou vinho, couza commum sempre entre pessôas intimas"20.

Quando certa facção da elite assumia o controle político-institucional, via câmara, encontrava resistência na facção rival. Estas disputas transbordavam o mundo da elite e se propagavam nos meios populares, por laços de fidelidade ou apadrinhamento. Daí que a resistência tornava-se regra e dificultava a burocratização.

Pedidos para construção e, posteriormente, reforma da cadeia eram uma constante e começam nos primeiros tempos de elevação de Lençóes à vila. Em março de 1870, a câmara, por "falta de prática", informa ter deixado de enviar ao presidente da província o orçamento dos serviços de que a vila necessitava, entre eles "um puchado na insignificante cadêa desta Villa para mais comodidade de poder servir também de quartel”.

Uma comissão encarregada de fazer uma avaliação do estado da mesma concluiu, em novembro de 1876, que "de prestável somente as telhas as poucas madeiras de cima as portas e janellas, e as grades de ferro" ${ }^{21}$.

Em dezembro daquele ano de 1876, o juiz Amaral Gurgel também reclama do estado da cadeia e aproveita a deixa para reivindicar ao presidente da província reforço policial, uma vez que sete praças para um vasto território era um número irrisório. o juiz descreve o território, enumera suas freguesias e afirma que a força de sete guardas é diminuta para as neceesidades da Vila e seus arredores:

Sei que criminosos passeiam na freguesia de São Pedro, sei que perto da Villa de Santa Crus está homisiado um criminoso de morte da Faxina, sei que em uma fazenda retirada desta quinze leguas tem pelo menos cinco criminosos, e como capturalos? Portanto é justo que V. Exa. mande acrescentar a força policial para este termo até o numero de vinte praças e um Alferes, para este

\footnotetext{
${ }^{19}$ Caixa 296, Ordem 1091, Ofícios diversos 1849-1891, Pasta 2, AESP

${ }^{20}$ Caixa 44, Ordem 4789 Anos 1872-1891, AESP.

${ }^{21}$ Caixa 296, Ordem 1091, Ofícios diversos 1849-1891, AESP.
} 
partir daqui nas occasiões precisas em diligencia segundo as necessidades que offerecerem.

Poucos meses antes, em agosto de 1876, Amaral Gurgel, então juiz municipal de Lençóes, descrevia a situação em que se encontrava a vila com relação à segurança. Sem meios de efetuar diligência para a captura de criminosos e com uma cadeia sem a mínima segurança, vê-se impotente frente às neceesidades. Criminosos "conservão-se passificamente em seus sitios" e:

por mais de uma vês recommendado aos subdelegados a prisão dos criminosos, elles respondem que não podem captura-los por falta de forças, e tem receio de ficarem desmoralisados porque os amigos ou parentes de qualquer criminoso em vista de não haver força podem tirar do poder da autoridade policial o preso, como já succedeu no anno passado na freguesia São Pedro do Turvo.

Anos depois, em março de 1887, a falta de quadros ainda é um empecilho ao regular funcionamento da justiça. Naquele ano, o juiz pede, pela terceira vez, 8 praças para o destacamento da vila, visto que um importante réu, o capitão João Antonio Damasceno e Sousa (que anos antes havia sido delegado de polícia), estava a poucos dias de ser pronunciado. Com a força atual, afirma o juiz, "exigir do Delegado de Policia a captura desse réo é concorrer para que o Delegado fique desmoralisado ou que soffra qualquer offensa". E passa a relatar um episódio que ilustra a precária situação da vila:

Hontem o Delegado Capitão Moura Telles, voltou de uma diligencia que foi capturar o réo Antonio Ivo, de crime de homicídio, isto por denuncia de moradores, que este é homem turbulento e criminoso, más o Capitão Moura Telles cumpridor dos seus deveres, acompanhou a escolta, andou dose horas e pela madrugada setiarão a caza do criminoso, este vendo que era preso desfexou alguns tiros que não offendeu a escolta, esta disparou dois tiros pela tenás resistencia do criminoso, a escolta temendo ser offendida, apesar de serem sete praças correrão deixarão o Capitão Moura, sómente diante do perigo que sustentou com todo denodo a sua posição recostado sobre um tronco de alvore distante do criminosos tres braças a espera da escolta, más esta como não voltasse o Delegado abandonou o seu posto. o Comandante do destacamento Ildefonso Antonio Pereira foi o $1^{\text {o }}$ que correu, os seus companheiros acompanharão. Eis a rasão porque tenho pedido a V. Excia. 8 praças e insisto atendendo que temos diversos criminoso.

O juiz defende a demissão incontinente e posterior substituição do delegado Ildefonso e dos soldados fujões. Alarmado, o juiz afirma que o capitão Damasceno e Sousa "prometteu publicamente que quando for pronunciado entrará nesta Villa com 30 homens para maltratar as 
autoridades". Temeroso, diz ainda que, não sendo atendido, pedirá licença e se retirará da comarca "para não sofrer desacato".

Em 1880, o promotor Marcolino Pinto Cabral relatava às autoridades que a "cadeia não offerece a menor segurança e no entretanto temos um prezo de muita importância com V.Ex. ${ }^{\text {cia }}$ deve saber" e que estava "uma das janellas da cadeia cahida e essa não há quem mande collocal-a". Na mesma correspondência, tratava da situação de penúria que atingia os presos pobres, pois a quantia de 340 réis diários dados ao fornecedor para que os alimentasse era muito pouco. Queixando-se ao subdelegado, este respondeu:

[...] que era para elles, que estavão cumprindo sentença, mais um castigo e que a providencia que pretendia tomar, era dizer ao colector que mandasse dar diariamente a cada um os 340 réis p. ․ comprar pão, quando o Snr. Presidente, infelizmente, nem aqui há uma padaria.

Em fevereiro de 1877, os vereadores fizeram chegar ao governo da província a necessidade de se criar uma comarca para atender "o vasto terreno occupado pela Comarca de Botucatu", ficando Lençóes, por sua importância, cabeça de comarca. A comarca seria instalada em outubro daquele mesmo ano, mas os problemas nem por isso deixaram de ser constantes. 0 primeiro juiz foi Joaquim Antonio do Amaral Gurgel.

Alguns anos (janeiro de 1882) depois de assumir e estando vaga a promotoria da comarca reclama da falta de quem aceite ocupá-la:

[...] nas condições de desempenhar os seus deveres, com independencia e imparcialidade, ella era por necessidade de recahir em pessôa que não merecerá a confiança do Juiz na occasião como esta, que está marcado a sessão do Jury para o dia 28 do corrente mês, que ouço dizer que entrarão na Cadeia 5 criminosos de importancia, e protegidos, para serem submettidos a julgamento.

Falta ou despreparo do promotor permeiam as correspondências entre o juiz da vila e as autoridades provinciais. Numa delas, em novembro de 1888, o juiz informava que o promotor Augusto Elizio de Castro Fonseca pedira licença pra retirar-se para Pernambuco, onde tinha família, prejudicando a comarca que "por suas condições especiaes" não poderia ficar sem a presença de um. E mais, o juiz asseverava que o promotor é inexperiente, pouco sensato e bastante desmoralizado, além de ser um

[...] instrumento cego de um dos grupos da terra e justamente d'aquelle cujo cabeça tem particular interesse em conservar as águas revoltas. Mette-se em pagodes á monte e anda arrombando portas, enfim é um anarchista, e não inspira confiança. 
Apenas um mês depois de assumir, juiz Amaral Gurgel já tinha dúvidas em como proceder com relação a algumas questões:

Tenho idéia de ter visto publicado um Aviso do Ministério da Justiça do anno 1873 dispensando o Juiz de Direito de fazer sessão do Jury quando não houver reo preso ou afiançado. Entretanto examinando as colleções de Leis do referido anno e o relatório do Ministério da Justiça, não encontrei o referido Aviso. Em vista disso submetto a illustrada consideração de V.Ex. ${ }^{\text {cia }}$ para resolver a respeito.

As dúvidas persistem neste lento processo de construção de todo um saber jurídico por parte daquele que era o encarregado da justiça no sertão. Sabendo que era proibido o exercício da medicina por aqueles que não eram "facultativos", o juiz tinha dúvidas sobre as localidades que não dispunham de nenhum profissional formado na área, perguntando se, onde não há facultativo, "o licenciado pela Junta Central da Hygiene Publica, ou outro que tem algum conhecimento pratico da medicina pela força de necessidade poderá qualquer delles exercer a medicina temporariamente uma ves que nada exige pelo seu trabalho".

Indagava o mesmo a respeito de alguém que tivesse um conhecimento prático na "sciencia" da "Homeophatia" e sobre a venda de medicamentos por negociantes de fazendas, ferragens e armarinhos. Uma das dúvidas é algo prosaico: se no caso de proibição da venda pelos negociantes, se estes poderiam dá-los a seus fregueses, uma vez que o artigo de um citado regulamento cogitava apenas da venda dos medicamentos, não de sua doação.

As autoridades provinciais responderam pela negativa quanto à primeira questão:

Só pode exercer a medicina ou qualquer de seus ramos aquelle que tiver titulo conferido pelas escolas de medicina do Brasil ou aquelle que, formados em escolas ou universidades estrangeiras, fizerem perante aquellas exame de sufficiencia. Esta é a pratica actual. Ora, esta disposição rege em absoluto, e a circunstancia de não haver na localidade profissionaes, não pode autorisar o exercicio de individuos fora d'aquellas condições, ainda mesmo que nada exijam pelo seo trabalho, pois que a saude publica não pode ficar sujeita ao capricho e a ignorancia dos amadores da medicina.

A homeopatia, diz a resposta, não era cogitada no "Regulamento de 1851", nem oficialmente autorizada, podendo, portanto, ser seu emprego tolerado. Quanto à questão da venda ou doação de medicamentos por parte de negociantes, as autoridades são enfáticas ao afirmar que: 
Se taes negociantes não podem ter drogas ou medicamentos como os podem dar? Nesta hypothese, quem vende não é mais criminoso do que quem dá. A gravidade da infracção não se mede por esta bitola. O crime está na administração das drogas e medicamentos e sua presumivel nocividade, por ser feita por pessôa não autorisada legalmente. ${ }^{22}$

No ano seguinte à sua posse, o juiz Amaral Gurgel encaminhava ao governo provincial uma correspondência na qual elencava uma série de questões as quais lhe causavam dúvidas. As dúvidas do juiz mostram sua ainda pouca familiaridade com os temas que chegavam às suas mãos referentes aos problemas de um mundo de fronteira. Amaral Gurgel construía, aos trancos e barrancos, a ordem judiciária da vila. Indagava ele, por exemplo, "se nos crimes afiançáveis e policiaes sendo o delinqüente official da guarda nacional ou o outro equiparado pelo previlegio que gosa, uma vez que não tenha prisão especial deve ser conservado preso na Casa da Câmara Municipal?" Ao que se responde que tais pessoas "não devem ser recolhidos a Cadeia, havendo prisão própria ou mais decente" ${ }^{23}$.

No início de 1881, uma questão de medição de terras revela a precariedade da justiça em arbitrar conflitos quando a força legal era impotente frente à particular. Terras pertencentes a Francisco Fernandes Borges não puderam ser medidas:

[...] em virtude da opposição forma que fasia o Capitão João Antonio Damaceno e Sousa, que apresentou no acto da audiencia com grupo de capangas, que procurou provocar com palavras offencivas o advogado do requerente Borges, e dizendo posteriormente a audiencia que essa medição não se fasia. Não tendo este juiso força para fazer garantir os trabalhos da medição, pois que contava certo haver conflito, resolvo adiar pra o dia 7 do proscimo mes de Fevereiro. ${ }^{24}$

As paixões partidárias foram responsáveis por outros tantos conflitos na vila. Em 1872, desavenças quanto à "inauguração” da Assembléia Paroquial pôs duas facções frente à frente na praça da matriz. De um lado, membros da Guarda Nacional, liderado pelo "bellicato comandante superior interino Joaquim de Oliveira Lima" que, seguido por um cortejo composto de muitos familiares seus e "cento e tantos homens ostensivamente armados fes sua solene entrada na matriz". O relatório do juiz de paz informa que:

\footnotetext{
${ }^{22}$ Caixa 44, Ordem 4789, Anos 1872-1891, AESP..

${ }^{23}$ Ibidem.

${ }^{24}$ Caixa 296, Ordem 1091, Ofícios Diversos 1849-1891, AESP.
} 
[...] assentes de afrontar o colosso, que era um arsenal de guerra, pondo-nos em marcha para a matriz, levando a frente o pavilhão nacional, e, chegados a praça, fomos encontrados pelo vigário padre Vito Filamore, que temendo effusão de sangue, nos veio pedir para alli determos em quanto elle ia conferenciar com o comandante superior interino[...]..$^{25}$

O padre conseguiu desmobilizar os revoltosos.

Na noite de 21 de abril de 1881, o boticário Francisco Telles do Nascimento estava com alguns amigos no interior de sua residência. Ouviu baterem à porta, abriu-a e, não encontrando ninguém, saiu à rua e encontrou com um grupo de 6 homens que diziam querer falar-lhe. Convidou-os a entrar e viu, então, que estava todos armados e que eram seus desafetos políticos. Entre eles estava o promotor público Marcolino Pinto Cabral - em completo estado de embriaguez, segundo Telles - respondendo-lhe que vinham tirar satisfação e se vingar. o boticário julgou que vinham assassiná-lo, não o fazendo por estar com visitas em casa, o que os agressores ignoravam. Os demais elementos eram os capitães Joaquim Moreira Machado de Oliveira e João Antonio Damasceno e Sousa, o tabelião Julio César de Oliveira, o solicitador Theodolindo César Ramos e José Eufrosino Damasceno e Sousa. Repelidos, os homens prometeram voltar.

O episódio prosseguiu dias depois. Nas palavras de Telles, no dia 13 de maio, à noite:

[...] os mesmos homens improvisarão uma passeata com musica pela rua, para sómente me insultarem, soltando dois foguetes deitados para minha caza, cuja explosão foi sobre o telhado. Em virtude do occorrido reuni gente em nossa caza, e mandei comprar foguetes, pois que se a provocação continuasse com foguetes inclinados, mandaria da mesma forma lhes lançar foguetes no grupo e esperava as consequencias, felizmente meus inimigos sabendo derão por finda a passeata, e dispersarão-se, acodio também em nosso soccorro o Delegado de Policia com a força. ${ }^{26}$

Em agosto de 1882, eleitores liberais requisitaram a influência do Centro Liberal da capital paulista para conseguir a demissão do promotor público da vila, Simão Eugenio de Oliveira Lima, por ser este conservador. Pelo menos era esta a alegação do juiz de Lençóes para tentar barrar a demissão, alegando ao presidente da província que:

O actual Promotor Publico, é um moço muito sensato cumpridor dos seus deveres, não se envolve em política e nem é eleitor desta Parochia, querem

\footnotetext{
${ }^{25}$ Ibidem.

${ }^{26}$ Ibidem.
} 
demissão delle, porque existem neste Termo réos de crimes de morte revestidos de pervercidade que desejão pôr em julgamento do Jury, como o Promotor é incapaz de transigir com a Justiça, motivo porque não serve para Promotor, elles desejam antes um homem leigo para Promotor capás de fazer tudo.

Em 1882, o já citado boticário Francisco Telles do Nascimento acusou, em dois artigos publicados no jornal Província de São Paulo, o juiz de Lençóes Joaquim Antonio do Amaral Gurgel, de manter casa de jogo em sua residência. Em retaliação Amaral Gurgel excluiu-o do alistamento eleitoral, “por não poder provar a qualidade e a renda legal". De acordo com o juiz, Telles recorreu ao tabelião Julio César, a fim de que este lhe fornecesse um documento falso que lhe garantisse a entrada no rol dos votantes. Diante da negativa, foi:

[...] o Tabelião espancado, que deixarão por morto, o facto deu-se em uma noite escura os delinqüentes occultarão, mas a opinião publica aponta elle como mandante. Fiserão o auto do corpo de delicto, os ferimentos forão julgado que podiam ser que produsissem graves encommodos de saúde, e ficou archivado no cartório da Delegacia. Telles tem nesta Villa dois indivíduos taberneiros que vivem negociando sobre a fiança delle, são estes os seus capangas, são estes que a opinião publica aponta como mandatários no attentado contra o Tabellião. ${ }^{27}$

As eleições davam muito trabalho ao juiz Amaral Gurgel. As eleições do dia 21 de junho de 1883 deram motivo a novas queixas endereçadas à presidência da província. Mais uma vez, o epicentro das discussões envolve o nome do boticário Telles do Nascimento. Segundo o juiz, na eleição daquele dia, um "fósforo" eleitoral ${ }^{28}$, indiciado em processo, ordenou ao sargento enviado pelo delegado de polícia para acompanhar o processo, que retirasse do recinto os dois praças que ali estavam. Obedecendo à ordem, o sargento desmoralizava o delegado, "homem muito prudente e bem intencionado", segundo Amaral Gurgel, para quem:

[...] se o Delegado não fosse prudente poderia dar ordem de prisão pela desobediencia, más para evitar qualquer perturbação no processo eleitoral sómente mandou por meio de uma portaria que o sargento entrasse na prisão pelo crime de desobediencia, e mandou lavrar o auto de prisão. O Delegado é

\footnotetext{
${ }^{27}$ Ibidem.

28 "O fósforo era a pessoa que votava no lugar de um eleitor, ou seja, um impostor. A origem possível do vocábulo decorreria da semelhança da urna de madeira com uma caixa de fósforo e nesse sentido, o fósforo se dispunha a riscar, isto é, a votar em qualquer urna." (http://www.tse.jus.br/eleitor/glossario/ termos-iniciados-com-a-letra-f\#fosforo. Acesso: 09 outubro 2015).
} 
o Capitão João Antonio Damasceno e Sousa, independente bem intencionado pelo facto de não se prestar a ser instrumento do desordeiro Francisco Telles que aconselha o sargento para desobedecer, e este individuo ainda está sendo processado neste Termo.

Acaloradas discussões políticas agitavam o núcleo urbano da vila. No dia 10 de janeiro de 1885, uma discussão entre liberais e conservadores, por ocasião da eleição para a presidência da câmara, levou à saída do recinto daqueles últimos. Os liberais procederam à eleição e, quando os trabalhos estavam ultimados, foram surpreendidos com a chegada dos conservadores acompanhados dos poderosos membros da família Rocha. Segundo depoimento por escrito do porteiro da câmara, Candido de Moraes Mello, "estes senhores estavão em estado agitados, colericos, mostrando assim predisposições de má conseqüência" 29 .

Em 1887, seriam realizadas eleições para deputados provinciais. $\mathrm{O}$ ambiente, no entanto, causava temores no juiz substituto da comarca, Marcolino Pinto Cabral. Em ofício endereçado à presidência da província, Cabral, fazendo referência a acontecimentos de meses antes, temia, "pelos boatos que correm, com certeza a ordem publica tem de ser alterada pois que um grupo que pleitea a eleição, promete tomar desforra dos acontecimentos de 31 de março deste anno". Pedia que enviasse e deixasse à disposição do delegado de polícia da vila 15 praças para acompanhar a eleição.

Por muito tempo, sucederam-se os pedidos de reforço policial e de recursos para equipar a justiça com condições de vigiar os vastos sertões da fronteira oeste da província de São Paulo.

\section{Considerações finais}

A burocratização das administrações locais enfrentou obstáculos históricos para se consolidar, e hoje ainda se nota que não fincou raízes profundas que a deixem imune a interesses alheios.

No sertão paulista do século XIX não foi diferente, mas estes obstáculos foram potencializados pela condição de fronteira do povoamento, onde a construção de todo um aparato jurídico-político-religioso-educacional fez-se aos solavancos, encontrando poderosa resistência nos grupos familiares e nas relações de amizade.

${ }^{29}$ Ibidem. 


\section{Siglas}

AESP - Arquivo do Estado de São Paulo

ACMLP - Arquivo da Câmara Municipal de Lençóis Paulista / SP

ALESP-DAH - Arquivo da Assembléia Legislativa do Estado de São Paulo - Divisão de Acervo Histórico

ACB - Arquivo da Cúria de Botucatu / SP

Artigo recebido para publicação em 30/05/2015

Artigo aprovado para publicação em 04/11/2015 